\title{
PENERAPAN PEMBELAJARAN KONSEPTUAL INTERAKTIF BERBANTUAN MEDIA CMAPTOOLS UNTUK MEMINIMALKAN MISKONSEPSI
}

\section{IMPLEMENTATION OF INTERACTIVE CONCEPTUAL LEARNING HELPED BY THE MEDIA CMAPTOOLS TO MINIMIZE MISCONCEPTION}

\author{
Desy Eka Muliani \\ Prodi Pendidikan Fisika Sekolah Tinggi Keguruan dan Ilmu Pendidikan Adzkia Padang \\ E-mail: desyekam@gmail.com
}

Diterima: 10 Agustus 2019. Disetujui: 16 Oktober 2019. Dipublikasikan: 29 November 2019

\begin{abstract}
This study is aimed to comparative analysis of quantity of misconception, then student's attitude scale after applying conceptual interactive learning with cmaptools media. This research used quasy experiment with Randomized Control Group Pretest-Posttest design and descriptive methods. The research sample was class $X_{9}$ dan $X_{10}$ semester 2 of Senior High Scool at Cimahi. Instruments that used were concept understanding test with CRI, observation form, student's attitude scale form. Based on CRI analysis, the result were experiment class has more less misconception than control class. The result of student's attitude scale was almost of all students agree that applying conceptual interactive learning with cmaptools media can motivate, gain concept understanding and can be applied for another concept in physics.
\end{abstract}

Keywords: interactive conceptual learning, cmaptool, concept understanding

\begin{abstract}
Abstrak: Penelitian ini bertujuan menganalisis perbandingan kuantitas miskonsepsi, serta deskripsi skala sikap siswa. Metode penelitian yang digunakan quasy experiment dengan desain Randomized Control Group Pretest-Posttest dan metode deskriptif. Berdasarkan analisis CRI diperoleh kuantitas miskonsepsi pada kelas eksperimen lebih kecil dibanding kelas kontrol. Hasil skala sikap siswa menyatakan hampir seluruh siswa setuju bahwa pembelajaran konseptual interaktif berbantuan cmaptools dapat meningkatkan pemahaman konsep.
\end{abstract}

(C) 2019 Unit Riset dan Publikasi Ilmiah FTK UIN Raden Intan Lampung

Kata Kunci: pembelajaran konseptual interaktif, cmaptools, pemahaman konsep.

\section{PENDAHULUAN}

Menyikapi kemajuan teknologi dan informasi saat ini dibutuhkan pelaksanaan pendidikan yang berkualitas. Keberhasilan pendidikan tak lepas dari peran sekolah dan tentunya kualitas pembelajaran. Pembelajaran sains yang berkualitas di sekolah pada hakikatnya bertujuan tidak hanya memahami dan menguasai apa dan bagaimana sesuatu terjadi.

Pembelajaran yang terjadi dilapangan belum sesuai dengan apa yang diharapkan, kurangnya usaha pengembangan berpikir yang menuntun siswa untuk memiliki pemahaman konsep yang baik. Rendahnya kemampuan pemahaman konsep siswa tercermin dari data hasil studi pendahuluan di salah satu SMA Negeri di kota Cimahi, diperoleh nilai rata-rata pemahaman konsep siswa 40 dari skor ideal 100. Hal ini diduga ada kaitannya dengan proses pembelajaran yang terjadi. Hasil observasi menunjukkan bahwa pembelajaran di kelas lebih bersifat pasif dan menghafal, 
siswa kurang aktif karena pembelajaran lebih bersifat teacher center.

Dampak dari rendahnya pemahaman konsep, salah satunya yakni mempengaruhi rendahnya prestasi belajar siswa, karena pemahaman merupakan tahap awal siswa untuk memiliki kemampuan lebih tinggi lainnya seperti kemampuan pemecahan masalah, berpikir kritis, berpikir logis, dan kemampuan lainnya. Selain itu rendahnya pemahaman konsep juga dapat menyebabkan miskonsepsi pada siswa (Suparno, 2013) miskonsepsi siswa salah satunya disebabkan oleh tidak lengkap atau salahnya pemahaman yang diterima oleh siswa, penyebabnya adalah informasi serta data yang tidak lengkap sehingga siswa tidak dapat memahami konsep dengan baik.

Aspek pemahaman ini sangat penting, disebabkan karena bila siswa melakukan proses belajar mengajar, maka pertama kali yang akan dicapai dari tujuan belajar adalah memahami apa yang dipelajari. Salah satu pembelajaran yang diduga dapat digunakan untuk meningkatkan pemahaman konsep fisika adalah pembelajaran konseptual interaktif berbantuan media cmaptools.

Berdasarkan hasil penelitian terdahulu (Gusrial, 2009; Pelita, 2011; Suhandi, 2009) menunjukkan bahwa pembelajaran konseptual interaktif dapat lebih meningkatkan pemahaman konsep fisika dibandingkan dengan konvensional. Pembelajaran konseptual interaktif memiliki karakteristik inti yaitu menekankan pada penanaman konsep terlebih dahulu diawal pembelajaran, selalu ada pemantauan pemahaman konsep, menggunakan metode demonstrasi, sistem kaloborasi kelompok kecil, dan mengutamakan interaksi kelas (diskusi).

Pembelajaran konseptual interaktif berbantuan media camptools, diharapkan siswa lebih termotivasi untuk memahami pembelajaran. Cmaptools sebagai salah satu media pembelajaran berbasis peta konsep merupakan model pengetahuan visual diperkaya dengan sumber-sumber hypermedia (gambar, animasi, video, url html, dll).

\section{METODE PENELITIAN}

Metode yang digunakan dalam penelitian ini yaitu metode eksperimen semu (quasi experiment) dengan Randomized Control Group PretestPosttest dan metode deskriptif. Metode eksperimen semu bertujuan mengetahui sejauh mana perbedaan peningkatan pemahaman konsep yang dicapai siswa setelah menerima perlakuan dengan pembelajaran konseptual interaktif berbantuan media cmaptools dibandingkan dengan pembelajaran konseptual interaktif tanpa bantuan media cmaptools. Metode deskriptif untuk mendapatkan gambaran kuantitas miskonsepsi dan tanggapan siswa terhadap pembelajaran konseptual interaktif berbantuan media cmaptools.

Dalam penelitian ini, peneliti menempuh empat tahapan yaitu: Pendahuluan meliputi studi literatur, dan survey lapangan, kemudian tahap perencanaan dan penyusunan instrument meliputi, penentuan sampel, penyusunan RPP, mebuat kisi-kisi instrument, uji coba instrument, analisis soal hasil uji coba dan menyusun instrument tes. Tahapan ketiga pelaksanaan meliputi, melakukan pretes baik di kelas kontrol maupun kelas eksperimen, implementasi pembelajaran konseptual interaktif berbantuan cmaptools pada materi listrik dinamis dikelas eksperimen dan implementasi pembelajaran konseptual interaktif tanpa bantuan media cmaptools di kelas kontrol, setelah perlakuan dilaksanakan posttest baik di kelas eksperimen maupun kelas kontrol. Tahap keempat pengolahan data dan pelaporan meliputi, pengolahan data tanggapan siswa, lembar observasi keterlaksanaan, pretest dan posttest 
pemahaman konsep, kuantitas miskonsepsi dan kesimpulan dan saran.

Intrumen yang digunakan yaitu: 1) tes pemahaman konsep berbentuk pilihan ganda yang dibubuhi CRI, 2) Angket untuk mengetahui tanggapan siswa, 3) Lembar observasi. Untuk melihat tingkat signifikansi perbedaan dua rata-rata antara nilai pretest dan posttest. Pada pengolahan data ini, uji-t digunakan jika kedua data yang dibandingkan tersebut terdistribusi secara normal, jika kedua data yang dibandingkan tidak terdistribusi normal, uji perbandingan dua rata-rata dilakukan dengan menggunakan uji Mann-Whitney menggunakan SPSS versi 20, serta analisis gain, sedangkan analisis data kuantitatif dilakukan secara deskriptif.

\section{HASIL DAN PEMBAHASAN}

Pada bagian ini dipaparkan hasil penelitian beserta pembahasannya tentang penerapan pembelajaran konseptual interaktif berbantuan media cmaptools untuk meningkatkan pemahaman konsep fisika siswa SMA. Data dan informasi yang diolah berupa lembar observasi keterlaksanaan pembelajaran, tes pemahaman konsep yang telah diintegrasikan dengan identifikasi miskonsepsi dan hasil analisis skala sikap siswa terhadap penerapan pembelajaran konseptual interaktif berbantuan media cmaptools.

\section{Pelaksanaan Penelitian}

Proses pembelajaran dengan menggunakan pembelajaran konseptual interaktif berbantuan media cmaptools yang telah dilaksanakan oleh guru dan oleh siswa dalam pembelajaran, ditunjukkan dengan persentase keterlaksanaan model pembelajaran yang telah diobservasi oleh observer seperti yang ditunjukkan pada Tabel 1 .

Tabel 1. Persentase Keterlaksanaan Pembelajaran Konseptual Interaktif Berbantuan Cmaptools oleh Guru

\begin{tabular}{|c|c|c|c|}
\hline Pertemuan Ke- & Guru/Siswa & $\%$ & Keterlaksanaan dan Interpretasi \\
\hline \multirow[t]{2}{*}{1} & Guru & 100 & $\begin{array}{l}\text { Seluruh Kegiatan } \\
\text { Terlaksana }\end{array}$ \\
\hline & Siswa & 96,43 & $\begin{array}{l}\text { Hampir Seluruh Kegiatan } \\
\text { Terlaksana }\end{array}$ \\
\hline \multirow[t]{2}{*}{2} & Guru & 100 & $\begin{array}{l}\text { Seluruh Kegiatan } \\
\text { Terlaksana }\end{array}$ \\
\hline & Siswa & 98,21 & $\begin{array}{l}\text { Hampir Seluruh Kegiatan } \\
\text { Terlaksana }\end{array}$ \\
\hline \multirow[t]{2}{*}{3} & Guru & 100 & $\begin{array}{l}\text { Seluruh Kegiatan } \\
\text { Terlaksana }\end{array}$ \\
\hline & Siswa & 92,86 & $\begin{array}{l}\text { Hampir Seluruh Kegiatan } \\
\text { Terlaksana }\end{array}$ \\
\hline
\end{tabular}

Berdasarkan Tabel 1. dapat dilihat
bahwa guru dapat melaksanakan
pembelajaran sesuai dengan rencana.
Kegiatan pada setiap tahapan
pembelajaran konseptual interaktif
berbantuan media cmaptools dapat
terlaksana dan dilakukan oleh guru
dengan baik karena seluruh langkah-
langkah pembelajaran dapat dilaksanakan.
Persentase keterlaksanaan
pembelajaran oleh siswa pada ketiga
pertemuan, menyatakan hampir seluruh

kegiatan terlaksana. Hal tersebut disebabkan karena pada tahapan penggalian konsepsi awal siswa tidak mampu menjawab pertanyaan yang diajukan oleh guru, karena siswa belum mempelajari materinya, walaupun di SMP siswa pernah mempelajari, tapi sebagian besar siswa tidak mengingat tentang konsep tersebut. Pada pertemuan ketiga yakni tentang rangkaian seri dan rangkaian paralel, tahap demonstrasi lebih banyak menyita waktu, sehingga pada 
tahapan terakhir yakni siswa menjawab pertanyaan dari fenomena yang dikemukakan guru di awal pembelajaran sebagai motivasi tidak dapat terlaksana dengan baik karena keterbatasan waktu.

\section{Deskripsi Miskonsepsi Materi Listrik Dinamis}

Hasil analisis skor posttest siswa yang mengalami miskonsepsi pada kelas eksperimen dan kelas kontrol untuk tiap konsep listrik dinamis dianalisis dengan cara menghitung persentase. Persenatse miskonsepsi antara kelas eksperimen dan kelas kontrol diperlihatkan pada Gambar 1 .

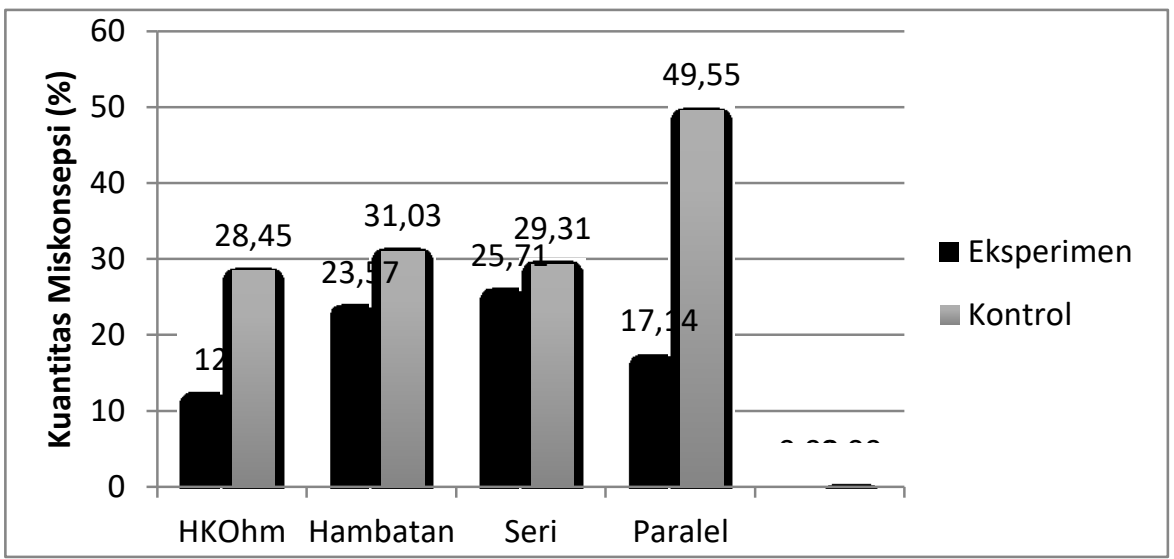

Gambar 1. Diagram Batang Perbandingan Kuantitas Miskonsepsi Siswa Konsep Listrik Dinami Antara Kelas Eksperimen dan Kelas Kontrol

Gambar 1 menunjukkan bahwa pada setiap konsep dalam listrik dinamis kuantitas miskonsepsi pada kelas eksperimen lebih kecil dibanding kelas kontrol. Konsep Hk.Ohm menunjukkan persentase miskonsepsi terkecil pada kelas eksperimen yakni sebesar 12\% sedangkan kelas kontrol sebesar 28,45\%. Pada konsep hambatan besar persentase kuantitas miskonsepsi antara kelas eksperimen dan kelas kontrol berturutturut yakni sebesar 23,57\% dan 31,03\%. Konsep rangkaian seri, menunjukkan persentase miskonsepsi pada kelas eksperimen sebesar $25,71 \%$ dan pada kelas kontrol sebesar 29,31\%. Pada konsep rangkaian paralel persentase miskonsepsi terbesar terdapat pada kelas kontrol yakni $49,55 \%$ sedangkan kelas eksperimen $17,14 \%$.

Pembelajaran konseptual interaktif berbantuan media cmaptools dapat mengurangi kuantitas miskonsepsi siswa, hal ini sejalan dengan pendapat (Badar alTabany, 2014) yang menyatakan bahwa pemetaan yang jelas dapat membantu menghindari miskonsepsi yang dibentuk siswa. Melalui penggunaan media cmaptool yang merupakan pemetaan konsep dengan bantuan komputer dapat lebih memudahkan siswa untuk memahami materi dan memperjelas materi, sehingga memperkecil miskonsepsi yang selama ini terjadi di siswa pada materi listrik dinamis.

\section{Skala Sikap Siswa Terhadap Pembelajaran Konseptual Interaktif Berbantuan Media Cmaptools}

Untuk mengetahui skala sikap siswa terhadap pembelajaran konseptual interaktif berbantuan media cmaptools pada materi listrik dinamis, dilakukan dengan membagikan lembar skala sikap kepada siswa kelas eksperimen yang diberikan perlakuan. Hasil rekapitulasi persentase skala sikap siswa terhadap pembelajaran konseptual interaktif berbantuan media cmaptools dapat dilihat pada Tabel 2. 
Tabel 2. Rekapitulasi Skala Sikap Siswa Terhadap Pendekatan Pembelajaran Konseptual Interaktif Berbantuan Media Cmaptools

\begin{tabular}{|c|c|c|c|}
\hline $\begin{array}{c}\text { Indikator } \\
\text { Pernyataan } \\
\end{array}$ & $\begin{array}{c}\text { No } \\
\text { Pernyataan } \\
\end{array}$ & $\begin{array}{l}\text { \% } \begin{array}{l}\text { Siswa yang } \\
\text { Setuju }\end{array} \\
\end{array}$ & $\begin{array}{l}\text { \% Siswa yang } \\
\text { Tidak Setuju }\end{array}$ \\
\hline $\begin{array}{l}\text { Pembelajaran konseptual interaktif } \\
\text { berbantuan media cmaptools termasuk } \\
\text { pembelajaran yang baru pertama dilakukan } \\
\text { dan dapat diterapkan untuk pembelajaran } \\
\text { selanjutnya }\end{array}$ & 1,dan 7 & 95,72 & 4,28 \\
\hline $\begin{array}{l}\text { Pembelajaran konseptual interaktif } \\
\text { berbantuan media cmaptools dapat memberi } \\
\text { motivasi siswa dalam belajar }\end{array}$ & 2 & 97,14 & 2,86 \\
\hline $\begin{array}{l}\text { Pembelajaran konseptual interaktif } \\
\text { berbantuan cmaptools dapat melatihkan } \\
\text { pemahaman konsep pada indikator } \\
\text { membandingkan, menafsirkan, menjelaskan } \\
\text { dan menyimpulkan. }\end{array}$ & $3,4,5,6$ & 96,43 & 3,57 \\
\hline
\end{tabular}

bahwa seluruh pernyataan pada lembar skala sikap siswa menyatakan hampir seluruh siswa setuju bahwa pembelajaran konseptual interaktif berbantuan cmaptools dapat lebih memotivasi siswa untuk memahami materi pembelajaran, dapat memfalitasi peningkatan kemampuan membandingkan, menafsirkan, menjelaskan, dan menyimpulkan serta dapat diterapkan pada pembelajaran fisika selanjutnya.

\section{KESIMPULAN}

Berdasarkan hasil penelitian yang telah dilakukan tentang pembelajaran konseptual interaktif berbantuan cmaptools dapat disimpulkan bahwa: Kuantitas miskonsepsi pada kelompok siswa yang mendapatkan pembelajaran konseptual interaktif berbantuan media cmaptools lebih kecil dibanding pada kelompok siswa yang mendapatkan pembelajaran konseptual interaktif tanpa bantuan media cmaptools. Hampir seluruh siswa menyetujui bahwa pembelajaran konseptual interaktif berbantuan media cmaptools dapat memotivasi siswa memahami materi pembelajaran, memfalitasi peningkatan kemampuan pemahaman konsep serta dapat diterapkan pada pembelajaran konten fisika yang lain
Badar al-Tabany, T. I. (2014). Mendesain Model Pembelajaran Inovatif, Progresif, dan Kontekstual. Jakarta: Prenadamedia Group.

Gusrial. (2009). Penggunaan Media Simulasi Virtual Pada Pembelajaran Dengan Pendekatan Konseptual Interaktif Untuk Meningkatkan Pemahaman Konsep Dan Meminimalkan Kuantitas Miskonsepsi Pada Materi Kalor. Pascasarjana Universitas Pendidikan Indonesia.

Pelita, P. D. (2011). Efektifitas Penggunaan Video Based Laboratory pada Pembelajaran Konseptual Interaktif dalam Meningkatkan Pemahaman Konsep, Pemahaman Grafik, dan Keterampilan Berpikir Kritis. Pascasarjana Universitas Pendidikan Indonesia.

Suhandi, A. (2009). Efektivitas penggunaan Media Simulasi Virtual pada Pnedekatan Pembelajaran Konseptual Interaktif dalam Meningkatkan Pemahaman Konsep dan Meminimalkan Miskonsepsi. Laporan Penelitian.

Suparno, P. (2013). Miskonsepsi \& Perubahan Konsep dalam Pendidikan Fisika. Jakarta: PT Grasindo. 